\title{
Money Stock Control and Its Implications for Monetary Policy"
}

\author{
by ALBERT E, BURGER, LIONEL KALISH III, and CHRISTOPHER T, BABB
}

In the last two years there has been an increased concern within the Federal Reserve System about the role of monetary aggregates in policy, and about the operating procedures implicit in the policy directive of the Federal Open Market Committee. A collection of studies on these subjects, Open Market Poliches and Operating Procedures - Stafy Studies, was published by the Board of Governors in 1971. Other economists have presented methods for analyzing the effects of different growth rates of money on policy objectives. An equally important subject is the controllability of different aggregates and the effect this controllability would have on the ability of policymakers to achieve policy objectives.

This article presents a procedure that could be used by the Federal Reserve System to control the growth of the money stock and a method for evaluating the effect of this control procedure on the ability of policymakers to achieve their policy objectives.

A growing volume of research has demonstrated that changes in the money stock are a reliable summary measure of the effect of monetary policy actions on economic activity. One result of this research has been the suggestion that the monetary authorities could best achieve ultimate policy objectives, such as full employment and stable prices, by controlling the growth rate of the money stock. Such a suggestion requires (1) an operational procedure for controlling money, and (2) a means of assessing the implications of such a procedure for the ability of policymakers to achieve their policy objectives.

A possible procedure for monetary policy includes:

(1) The Federal Open Market Committee (FOMC) decides upor the ultimate objectives of monetary policy, stich as desired growth rates for real output and prices, and a desired level of employment.

(2) These ultimate objectives are related to a growth rate of money, and the FOMC issues a "direc-

\footnotetext{
"The authors wish to express their thanks to the many people who read earlier drafts of this article. A special obligation is due the following economists who, in working sessions or otherwise, offered specific comments: Professors Milton Friedman, Arnold Zellner, Robert Gordon, Richard Zecher, Stanley Fisher, Allan Meltzer, Michele Fratianni, William Yohe, David Fand, and Messrs. Paul Meek and Wolfgang Gebauer. As always, we benefited from comments and criticism of the research staff at the Federal Reserve Bank of St. Louis, The procedures and conclusions are the responsibility of the authors and do not necessarily reflect the view of any of the commentators on the article or the Federal Reserve System.
}

tive" to the Trading Desk to obtain this growth rate for money. ${ }^{1}$

(3) The Trading Desk uses open market operations to achieve the growth ate of money which is consistent with the policymaker's objectives.

This article is concerned with the actual implementation of policy decisions. It is not concerned with how the policymakers decide upon their ultimate objectives, or with the specific way in which these objectives are related to a growth rate for money. The policy objectives are taken as given. Converting policy objectives into a desired growth rate of money requires information on the linkage between changes in the growth rate of the money stock and the ultimate objectives, Such information can be derived from competing models of income or spending determination.

This article presents a procedure the Federal Reserve could use to control money and a method for evaluating the effect of this control on the policymaker's ability to achieve GNP objectives. The money stock control procedure requires only that the Federal Reserve has information about the previous three

\footnotetext{
${ }^{1}$ The FOMC issues a policy directive to the New York Fed. eral Reserve Bank. The rlading Desk at the New York Bank carries out day-to-day open market transactions (purchase and sale of Government securities) for the System. The text of each policy directive issued by the FOMC is made public about 90 days after each FOMC meeting and published in the Federal Reserve Bulletin.
} 
month's values of the money multiplier and the effect of reserve requirement changes on nember bank reserves. Using a simulation technique, some empirical evidence is presented on the control the Federal Reserve could expect to exercise, using this procedure, over the growth of the money stock, and the effect of such control on the Federal Reserve's ability to attain its policy objectives. The technical details of the money stock control procedure, the simulation procedture, and the development of the statistic for assessing the influence of money stock control on achieving policy objectives, are discussed in the Appendix to the article and in a working paper of technical appendices available upon request from this Bank:"

\section{Money Stock Control Procedure}

There are two major ways in which the Federal Reserve might operate to control the growth of money. One way is to estimate the money market conditions that would be consistent with the growth rate of money stated in the directive, and then operate to achieve these conditions in the money market. This approach might involve choosing bounds for the Federal funds rate and free reserves and then operating on a day-to-day basis to maintain money market conditions within these bounds. A second method of money stock control, the one discussed in this article, involves estimating the changes in the source base (or some other reserve aggregate) required to achieve the policy determined growth path for money. The Federal Reserve would then operate on a day-to-day basis to determine the growth of the source base.

The money stock control procedure used in this article is developed from a multiplier-base framework, within which the money stock $(M)$ is expressed as:

$$
\mathrm{M}=\mathrm{mB}
$$

In this expression B denotes the net source base and $m$ represents the money multiplier. An increase in Federal Reserve holdings of securities, float, the gold stock, and Treasury currency outstanding will increase the net source base. An increase in Treastry deposits

2 Albert E. Burger, Lionel Kalish III and Christopher T. Babb. "Money Stock Control and Its Implications for Mone" tary Policy: Technical Appendices," Working Paper No. 14, Federal Reserve Bank of St. Louis, October $197 \mathrm{I}$.

These two methods of money stock control are not independent of each other. Open market actions taken to determine money narket conditions will influence the growth of the base, and actions taken to influence the base will affect shoft-term money market conditions. See, Albert E. Burger, "The Implementation Problem of Monetary Policy," this Review (March 1971). at the Federal Reserve, Treasury cash holdings, and other deposits and other Federal Reserve accounts will decrease the net source base. A complete listing of the sources and uses of base money and the relationships between the net source base, source base, and monetary base are given in Table $\mathrm{I}$.

The net source base is tuken as the control variable for the process.t From the sources side, the major component of the net source base (about 75 per cent) is Federal Reserve holdings of Government securities. The Federal Reserve is assumed to be able to accurately measure and determine the magnitude of the base within a monthly period. Evidence on the accuracy with which the Federal Reserve has been able to forecast and measure the net source base is presented in the working paper of technical appendices. ${ }^{5}$

The money multiplier ( $m$ ) summarizes all other factors involved in the money supply process. The money multiplier responds to portfolio decisions by the commercial banks, the Treasury, and the public. Also included in this formulation of the multiplier are the influences of reserve requirement changes, the discount rate, and Regulation Q."

In our money stock control procedure the Federal Reserve decides upon the desired growth rate of

The data requirements for controlling the net source base are as small or smalier than any of the other major aggregates commonly siggested as operating targets for the Federal Reserve. Richard Davis has shown that out of a wide range of possible aggregate targets the nonborrowed base and nonborrowed reserves would be the easiest targets for the Desk to hit. These two targets are entirely exogeneous with respect to open market operations. Contrary to other pro* posed targets, success in hitting these two targets does not depend upon the Desk offsetting items whose movements are functionally related to open market operations. See Richard G. Davis, "Short-Run Targets For Open Market Operations", Open Market Policies and Operating Procedures-Staff Studies, Board of Governors of the Federal Reserve System, July 1971, pp. 37.70.

5Burger, Kalish, Babb, Working Paper No. 14.

oThe money multiplier associated with the net source base is:

$$
m=\frac{1+k}{(r-b)(1+t+d)+k}
$$

where $k$ and $d$, respectively, are the ratios of currency held by the public and U.S. Government deposits at commercial banks to the demand deposit component of the money stock.

$r, b$, and $t$, respectively, are the ratios of bank reserves, member bank borrowings, and time deposits to commercial bank deposit liabilities (excluding interbank deposits).

The reserve ratio (through the dependence of banks desired excess reserves), the borrowing ratio and the time deposit ratio are all dependent upon credit market interest rates.

This formulation of the money multiplier is taken from the Brumer-Neltzer nonlinear money supoly hypothesis. Karl Bramner and Allan H. Meltzer, "Licuidity Treps for Money, Bank Credit and Interest Rates," Joumal of Political Eco nomy (Tanuary/February 1968), pp. 1-37. 


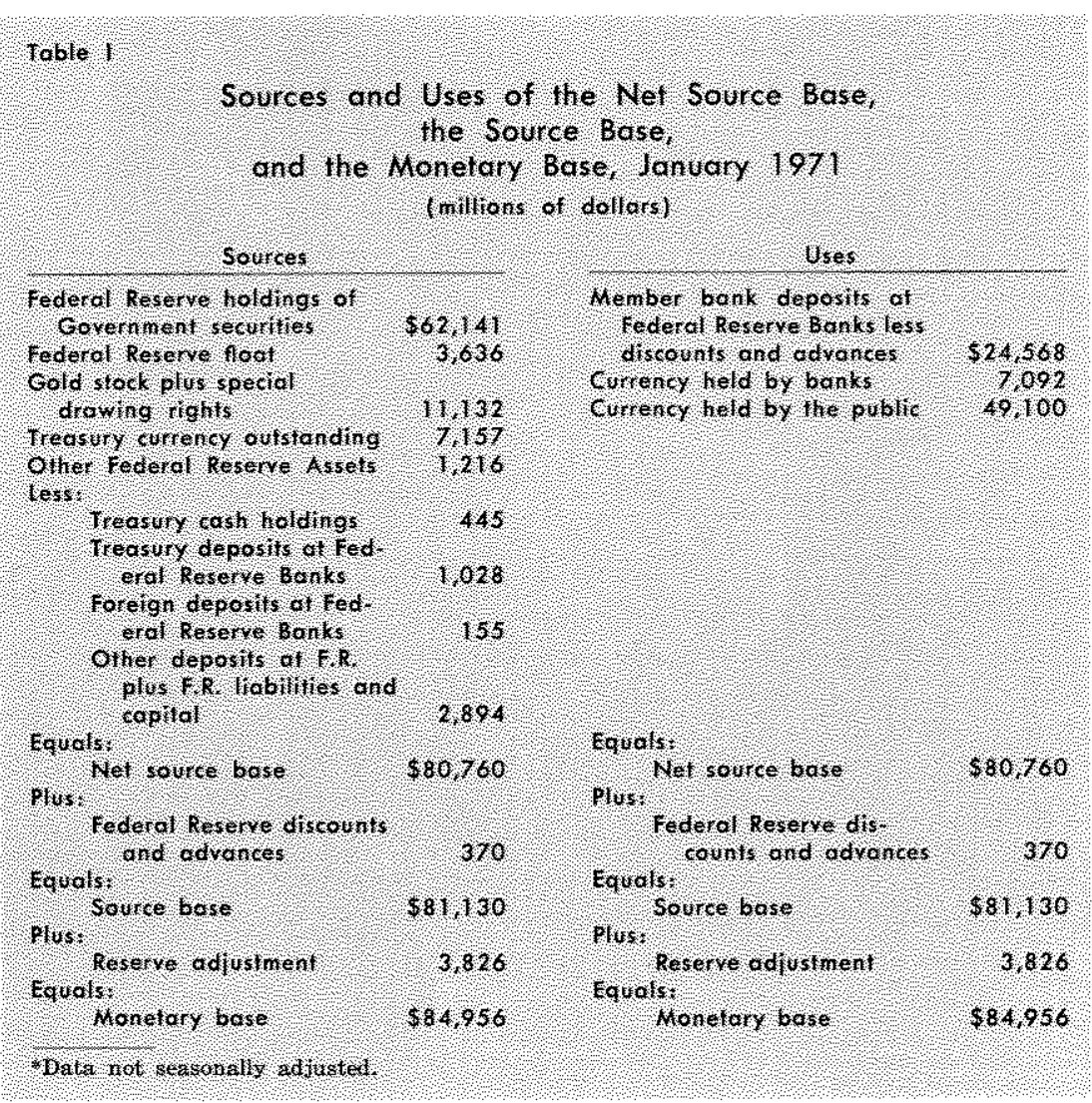

the expected squared deviation of the monthly value of money from its desired growth path. The net source base is assumed to be controllable on a dailyaverage monthly basis; therefore, within our control procedure monthly average multipliers are forecast. Having predicted the value for the month's money multiplier, and given the desired level for the money stock in that month, the average monthly value for the net source base necessary to achieve the desired growth of money is determined.

\section{Torecustimg the Hones Mulwiplies}

Next period's multiplier might be forecast by any one of the following methods:

(1) Definitional method - The multiplier-base framework is treated as an accounting identity. Some of the ratios of the multiplier are forecast using information about the various components (for example, Treasury deposits) acquired by the Desk in its daily operations. Other elements of the ratios are treated as being equal to their previous values with some adjustment for trend or seasonal variation. ${ }^{\top}$

(2) Regression method - The money multiplier is expressed as a function of variables that are known or are under the policy control of the Federal Reserve at the time each forecast is made. This relationship is estimated each period by multiple regression aralysis.

(3) Behavioral method - Each of the ratios of the multiplier is expressed as being dependent upon other variables such as interest rates, policy instruments, and other factors infuencing the deposit behavior of the banks and the public. This procedure requires predicting these other variables.

In this article, the second method is used. Each month's multiplier is forecast using the three-month moving average of past values of the multiplier, reserve adjustment magnitude in the forecast month,

"See Leonall C. Andersen, "A Study of Factors Affecting the Money Stock: Phase I," Federal Reserve Bulletin (October 1965 , p. 1379, and William G. DeWald "Monetary Control and the Distribution of Money," unpublished Ph.D. thesis, University of Mimnesota, 1963. 
dummy variables to account for seasonal factors, and an adjustment for autocorrelation. The values of these independent variables are known to the Federal Reserve. ${ }^{8}$

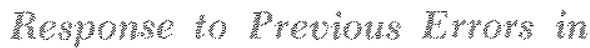 Whnets shock Control}

If there are errors in the forecasts of the money multiplier, the desired growth of money and the controlled growth of money will not be the same in every period. Under these conditions, further information is required to determine the optimal setting for the net source base. Suppose in period $t_{1}$ the money managers over-predict the money multiplier. Consequently, the achieved growth of money is less than the desired growth rate. What is the optimal setting for the net source base in period $t_{2}$ ? Should the money managers ignore the shortfall of money in $t_{1}$ ? Should they try and make up the shortfall of money in $t_{1}$ by setting the net source base in $t_{2}$ so that the growth of money is above the desired growth path? If they try and make up the shortfall, should they operate to make up all of the gap in t., or only part of the gap in $t_{2}$ and the remainder in succeeding periods?

There are many possible error-response mechanisms. Our procedure assumes that the money managers assign proportionally more weight to large errors in money stock control than small errors. Therefore, the error-response mechanism is designed to minimize the expected value of the squared deviations of controlled money from its policy chosen growth path." At the end of each control period, the money managers compute their error in money stock control. During the next control period the net source base is set approximately to make up last period's error ${ }^{10}$ The money stock control procedure is illustrated in the following exhibit.

8The Federal Reserve sets member bark reserve require ments. Since, under the current lagged reserve requirement procedure the effect on member bank required reserves of a change in reserve requirements effective this week depends upon member bank deposits subject to reserve requirements two weeks earlier, the Federal Reserve can accurately determine the effect of a change in reserve requirements on the reserve adjustment magnitude.

9This error-response mechanism assumes a quadratic loss function for the money managers. The control periods" base values are determined by minimizing the expected value of the loss function with respect to B. For a discussion of this procedure see the Appendix at the end of this article.

10If only the growth rate of money mattered, then the money managers would not attempt to make up last period's error in the level of money. Each period the money mangers wonld try to move along the desired growth path from where they were last period.

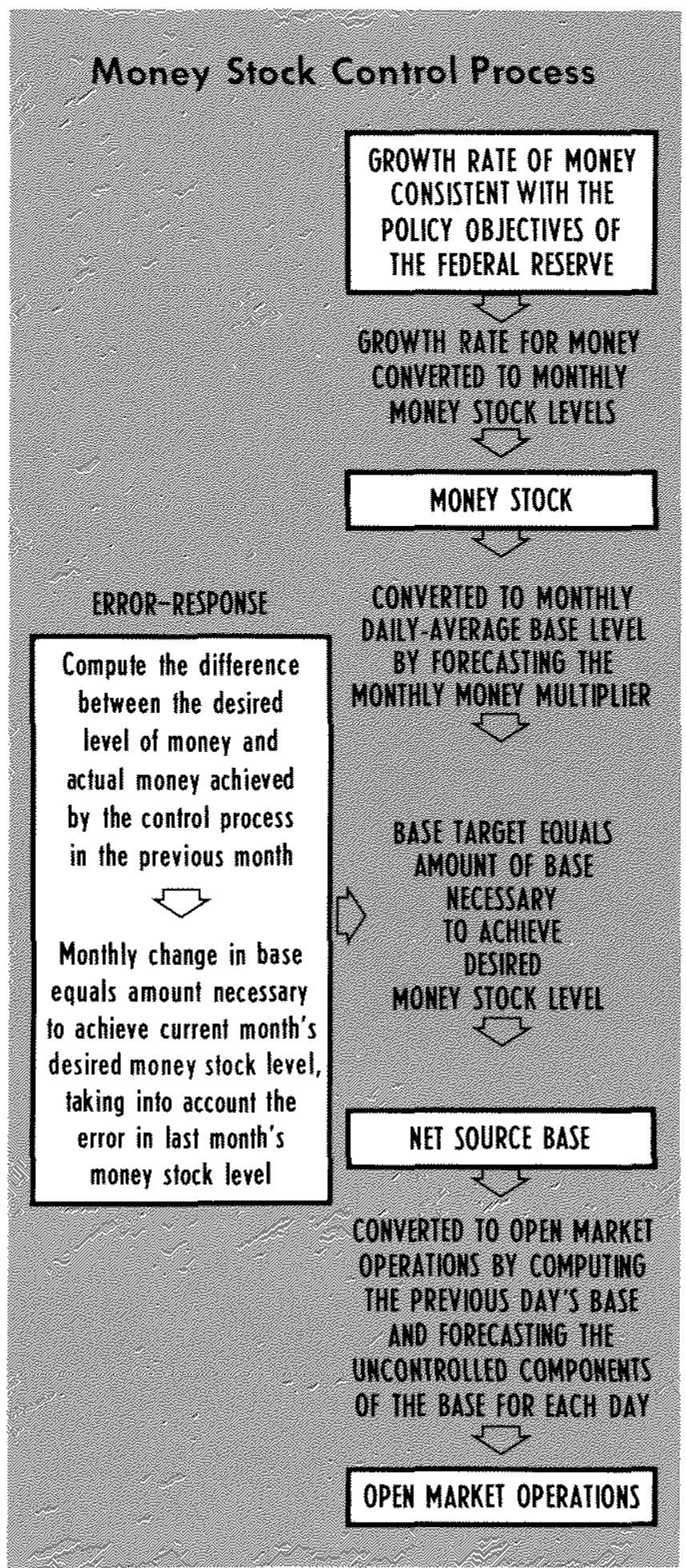

\section{Simulation of Money Stock Control and GNP}

How would the money stock control achieved by this procedure affect the ability of the Federal Reserve to achieve policy objectives? To gain some information on this question, the money stock control procedure was simulated over two sample periods, 
and the effects of these simulation results on GNP were andyzed. First, the method and results of simulating the money stock control procedure are presented. Then, the method of relating changes in money to $\mathrm{CNP}$ is discussed, and the results of simulating GNP when money is controlled without error are compared to the case where money is controlled by our procedure.

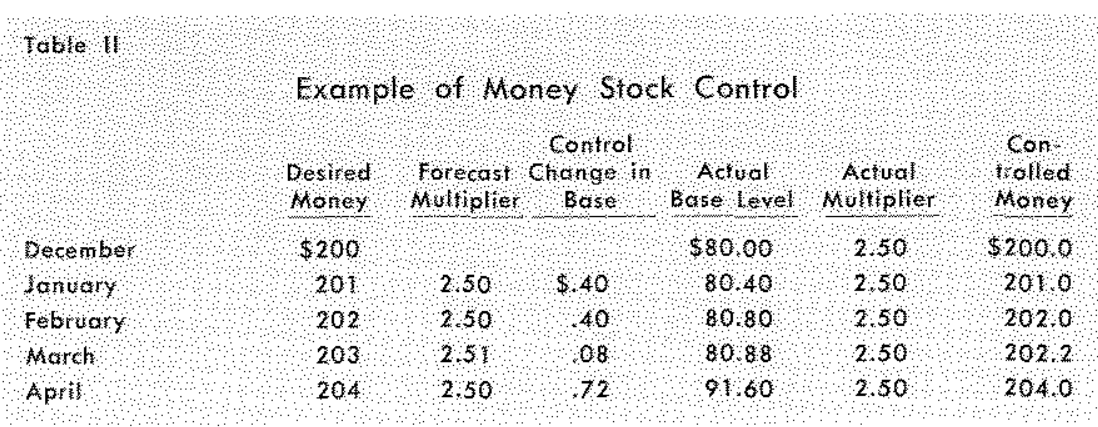

\section{Simulation of the Mones Stock Control procedme}

The following method was used to simalate money stock control:

(1) It was assumed that the policymakers choose a constant 4 per eent seusonally adjusted annual growth rate for money over the control period. 11

(2) The Federal Reserve adjusts the net source base in the current month to minimize the expected vahe of the squared deviation of the achieved monthly stock leve from the original 4 per cent growth line ${ }^{12}$

(3) Two control periods were chosen, 1962 through 1965 and 1966 throngh 1969. The base peniods were chosen as fouth quarter 1961 and fourtl quarter 1965.

(4) Each month, the money stock achieved by the control process (controlled money) is computed by taking the level of the net source base determined by our operating strategy and mutiplying it by the value of the multiplier that actually prevaled in that month. ${ }^{\text {: }}$ to the extent that the forecast multiplier is different from

\footnotetext{
"The desired growth rate of money was converted into desired monthy levels in the following manner: (1) the averages of money in IV/61 and IV/65 were taken as the base period; (2) these bise values were placed on Decem ber of 1961 and December 1965 ; (3) to compute the conversion factor for a 4 per cent growth rate we divided 0 by 12 to yield .00333; and (4) each month's desired money stock level was equal to (base month) + (base month) $x$ (number of months out from base month) $x$ (.00333). For example, December 1966 desired level equals $(167.0999)+(167.0999)(12)(.00333)=\$ 173.78$ bil lion, where 167.0999 equals the average of the last three months of 1965 .

This procedure yields a simple 4 per cent growt rate of money that appears as a straight line on an arthmetic scale. When computing guarter-to-quarter growth rates of money, however, the desired rate will be below 4 per cent near the end of the period. The results of our procedure would not have been altered if we had ased a compounded annual rate for money.

12This implies the Desk aims shightly below the desired growth path. See the Appendix at the end of this article.
}

the one that actually previled in that month, the achieved level of money is different from the desired.

The example in Table II, which may be used to illustrate this procedure, should be taken ony as an illustration. For the technical aspects of the procedure, especially the error-response mechanism, consult the Appendix at the end of this article. The frst column in Table II gives the monthly money stock levels consistent with the growth rate of money that the policymakers are advised will give them their desired policy objectives. The second column gives the forecast of the multiplier and the firth column gives the money multiplier that actually prevailed in each month. It is assumed that the comtrol procedure begins in January. For the first two months the Federal Teserve forecasts the multiplier with complete accuracy, the net sotroe base is changed by $\$ .4$ billion, and the money stock achieved by the control proce. dure equals the desired.

In March, however, there is an error in the forecast of the multiplier. The multiplier is forecast to be 2.51 , when it actually (the historical value) is 2.50. Consequently, the net source base is increased by only $\$ .08$ billon. Based on a forecast of 2.51 for the multiplier, the Federal Reserve expects that it would only have to supply $\$ .08$ billion of base, compared to $\$ .40$ bil lion in the previous two months. The result is an error in money stock control, controlled money is less than desired ( $\$ 2022$ billion compared with a desired level of $\$ 203$ billion). In. April, the rederal Reserve again forecasts the multiplier correctly. In this month the net source base is increased enough to make up last month's money stock error, and to hit the target of $\$ 204$ billion $^{14}$

${ }_{13}$ This procedure assumes the independence of changes in the net source base and the multiplier. If $m$ and $B$ are not independent, then whe actual multiplier might not be the one that prevailed, given a different change in $B$. For a discussion of this condition see Lionel Kalish, "A Study of Money Stock Control," Jounal of Finance (September $1970)$, pp. $761-776$.

1*This example uses an absolute loss function. To minimize the expected value of the squared deviations of money, the 
There are two prevalent views among economists conceruing the constancy of the desired rate of change of the money stock." One view is that the desired rate of change should never be altered (seasonally or cyclically). An altemative view holds that the monetary authorities have enough knowledge to alter the monetary growth rate seasonally and cyclically so that economic goals can be achieved better than if the rate were held constant. This particular issue does not affect our control procedure. The choice of a constant 4 per eent growth rate for money does not necessarily imply that a 4 per cent rate was a desirable monetary growth path for this period. Different desired rates of change mean only that the monetary authorities aim for different money stock levels, and combined with the same forcasted multiplier, the only difference in the operating strategy would bo a different change in the net source base.

Comparison of the sample periods - In order to gain information about the stability and robustness of the money stock control procedure, it was simulated during two historical periods which were markedly different with respect to the stability of the money multiplier. A change in any of the ratios appearing in the money multiplier (see footnote 6) can alter the value of the multiplier. These ratios are influenced by a number of factors such as market interest rates, the relationship between Regulation $Q$ ceiling rates and market rates, Treasury deposit decisions and changing patterns of tax payment dates, and introduction of changes in reserve requirements such as lagged requirements in September of 1968.

Therefore, in periods where there are sharp or erratic changes in the factors influencing the multiplier, one might expect the errors in predicting the multiplier to be larger than in periods where these factors remain constant or follow a steady trend. ${ }^{16}$ The fol-

actual change in base would be slightly less than $\$ .72$ billion.

I5See Milton Friedman, A Program For Monetary Stability (New York: Fordham University Press, 1959), and Franco Modigliani, "Some Empirical Tests of Monetary Management and of Nules Versus Discretion," Joumal of Political Economy, June 1964 , pp, $211-245$.

16The three interest rate series, commercial paper rates, market yields on Treasury bills, and long-term corporate bond rates, all exhibited much greater variation in the 1966-69 period. Examination of the $t, k$, and r-ratios also reveals a pattern of increased variability and sharp erratic movements in these ratios in the latter period. Of special interest is the behavior of the t-ratio (time deposits/demand deposits of money) in the two periods. In the 1962-65 period the t-ratio follows a steady upward trend with only a small amount of variation about the trend. In contrast, the t-ratio during the 1966-69 period exhibits wide and erratic fluctuations about its trend line. In the $1966-69$ period the contribution of the tratio to the month-to-month percentage change in the historical money stock had a mean of -.57 per lowing chart shows the variation of the money multiplier about its trend during both sample periods. Comparing the behavior of the historical money multiplice, it can be seen that it exhibited much greater variability in the 1966-69 sample period than in the 1962-65 period.

Empirical results - The results of simulating money stock control over the two sample periods are illustrated in the following chart. ${ }^{17}$ Table III presents several altemative ways of evaluating the results of our control procedure. This table presents controlled and desired levels, controlled and desired growth rates, and includes the mean, variance, mean square, and median of the errors.

Although the underlying conditions for money stock control are quite different in the two sample periods, the mean value of differences between controlled and desired growth rates is approximately the same in both periods. The nean value of deviations of controlled and desired levels is somewhat larger in the 1966-69 period. However, relative to the levels involved, the average percentage errors these deviations represent is approximately the same for the 1966-69 period as for the 1962-65 period.

The major difference between the results of the control procedure in the two periods is the occurrence of somewhat more frequent large deviations in the 1966-69 period. One indication of this difference is that the mean squared error for differences in the levels for the latter sample period is $\$ .62$ billion, compared to $\$ .36$ billion in the earlier period. Also, the average for the five largest percentage errors in the levels is 0.63 per cent in the latter period, compared to 0.58 per cent in the earlier period.

\section{Propections of GNP}

Policymakers are primarily concerned with attaining ultimate policy objectives, not just with controlling the growth of money. Controlling money is a means to an end, not the end in itself. In this section, the growth of GNP implied by a constant 4 per cent growth rate of money is chosen as the policy objective. This policy objective path for GNP (desired GNP) is then compared to the growth of GNP at-

cent and a variance of 4.48, compared to a mean of -2.29 per cent and a variance of .76 in the $1962-65$ period. There are pronomnced changes in the pattern of the tratio in the last half of 1966, in 1968, and during 1969. These changes reflect primarily the constraint of Regulation $Q$, which was an additional factor irtluencing the money supply process in the latter period.

${ }^{17}$ Chat plotting monthly values of controlled motey are given in Working Paper No. 14. 


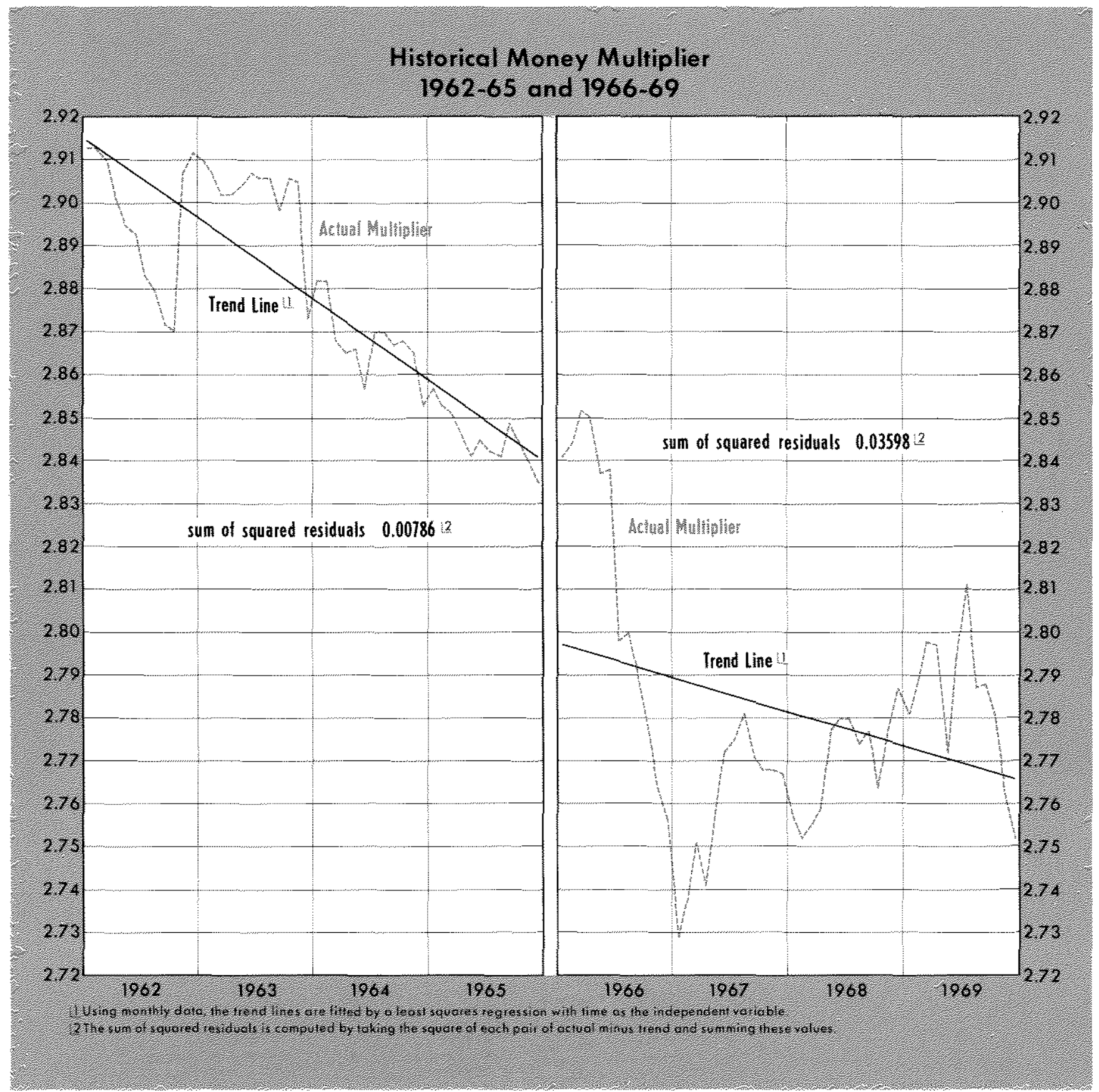

tained with controlled money. The following procedure was used:

(1) A model linking changes in the money stock to changes in nominal GNP was chosen. The model used was the Andersen-jordan $(A-f)$ spending equation which relates changes in GNP to current and lagged changes in the money stock and high employment govemment expenditures. ${ }^{14}$

${ }^{18}$ Leonal $\mathrm{C}$. Andersen and Jerry L. Jordat, "Monetary and Fiscal Actions: A Test of Their Relative Importance in Economic Stabilization," this Review (Novenber 1968), pp. $11-24$
(2) Actual high-employment goverument expenditures were used in both simulations. This procedure assumes that forecast high-employment government expenditures are always equal to the actual.

(3) The A-J equation was used to project quarterly GNP with a constant 4 per cent growth of money. This projected GNP path is the policy objective. Then, the A-I equation was used to project GNP for the same period, with the growth pattern of money as generated by our control procedure when aiming at a constant 4 per cent money stock growth. This is the GNP 
Table III

\begin{tabular}{|c|c|c|c|c|c|}
\hline & & & & & $\begin{array}{c}\text { (Billions of Dollars) } \\
1962-1965\end{array}$ \\
\hline Quarte & & $\begin{array}{c}\text { Controll } \\
\text { Level }\end{array}$ & & $\begin{array}{l}\text { Desired } \\
\text { Level }\end{array}$ & $\begin{array}{c}\text { Difference Belween } \\
\text { Controlled and Desired } \\
\text { Levels }\end{array}$ \\
\hline 1962 & $\begin{array}{l}\text { I } \\
\text { II } \\
\text { III } \\
\text { IV }\end{array}$ & $\begin{array}{r}\$ 146.1 \\
147.1 \\
148.2 \\
150.9\end{array}$ & & $\begin{array}{r}\$ 146.57 \\
148.03 \\
149.48 \\
150.94\end{array}$ & $\begin{array}{r}\$ .46 \\
-.91 \\
-1.26 \\
0\end{array}$ \\
\hline 1963 & $\begin{array}{l}\text { I } \\
\text { II } \\
\text { III } \\
\text { IV }\end{array}$ & $\begin{array}{l}151.6 \\
153.9 \\
155.6 \\
155.9\end{array}$ & & $\begin{array}{l}152.40 \\
153.85 \\
155.31 \\
156.76\end{array}$ & $\begin{array}{r}-.75 \\
.14 \\
.32 \\
-.86\end{array}$ \\
\hline 1964 & $\begin{array}{l}\text { I } \\
\text { II } \\
\text { III } \\
\text { IV }\end{array}$ & $\begin{array}{l}157.5 \\
159.0 \\
161.5 \\
162.0\end{array}$ & & $\begin{array}{l}158.22 \\
159.68 \\
161.13 \\
162.59\end{array}$ & $\begin{array}{r}-.72 \\
-. .66 \\
-.41 \\
-.53\end{array}$ \\
\hline 1965 & $\begin{array}{l}\text { I } \\
\text { II } \\
\text { III } \\
\text { IV }\end{array}$ & $\begin{array}{l}163.6 \\
165.3 \\
167.2 \\
168.6\end{array}$ & & $\begin{array}{l}164.04 \\
165.50 \\
166.95 \\
168.41\end{array}$ & $\begin{array}{r}-.36 \\
-.13 \\
.29 \\
.20\end{array}$ \\
\hline Mean & valu & viations: & $\begin{array}{l}\text { Absolute } \\
\text { With Sign }\end{array}$ & $\begin{array}{r}.50 \\
\ldots . .33\end{array}$ & \\
\hline Varian & ace & fions: & $\begin{array}{l}\text { Absolute } \\
\text { With Sign }\end{array}$ & $\begin{array}{l}.11 \\
.25\end{array}$ & \\
\hline Mean & squ & viations: & & .36 & \\
\hline
\end{tabular}

1962-1965
Controlled Compared to Desired Quarterly Averages of the Money Stock ${ }^{1}$

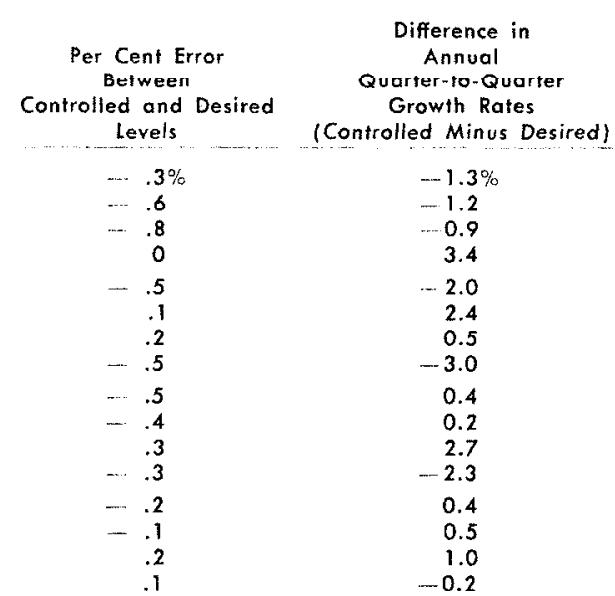

Mean of Per Cent Error (Absolute)

32
Mean of Difference in Growth Rates

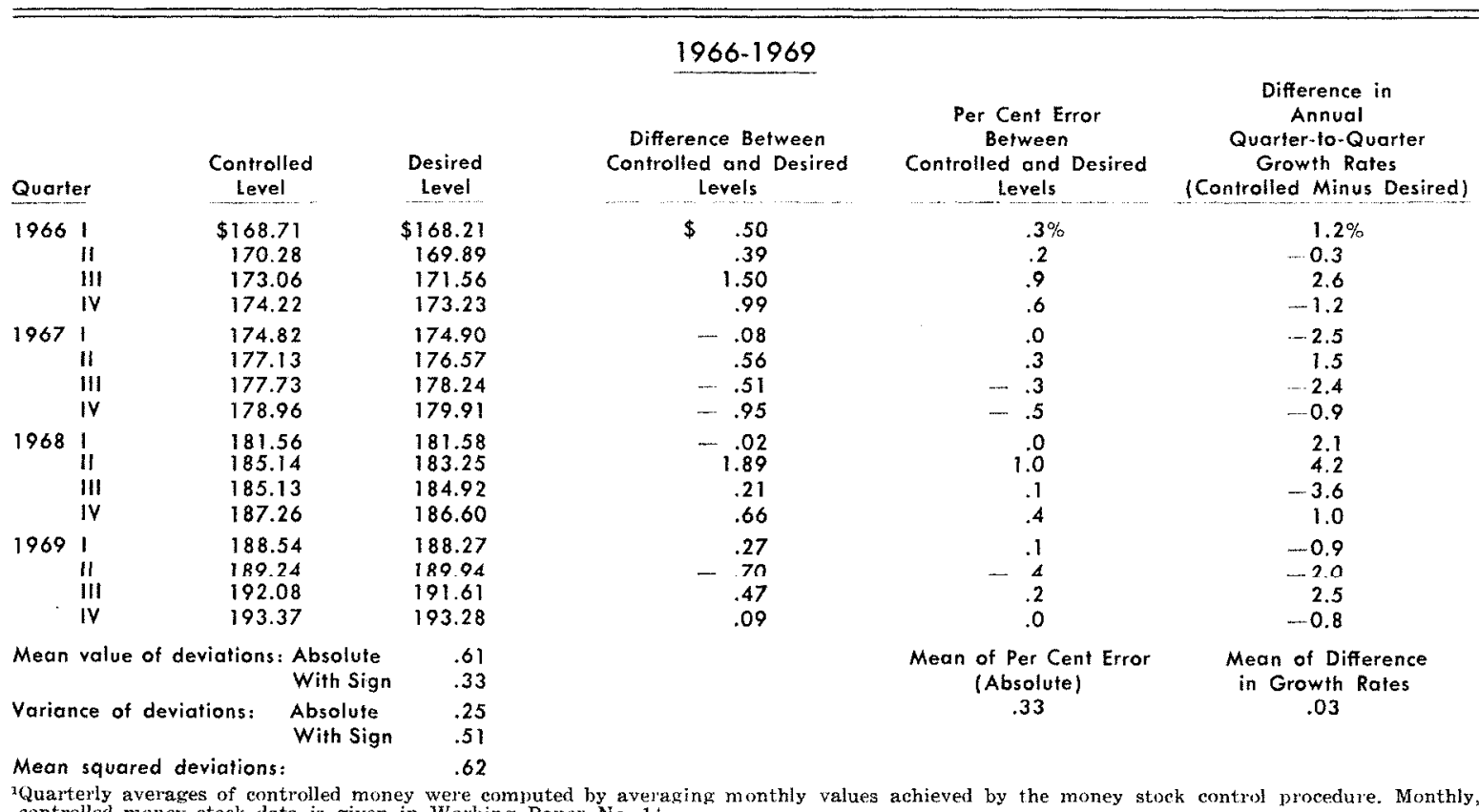

QQuarterly averages of controlled money were computed by aver'a

that would have actually resulted from policy actions. ${ }^{19}$

Several important points about this procedure should be emphasized. It is assumed that the GNP

19The desired quarterly growth rate of money was computed from the desired quarterly average money stock levels reported in Table III. that would have resulted from a constant 4 per cent growth rate of money and from controlled money would have been the GNP projected by the equation relating changes in money to changes in GNP. Therefore, the only source of error between the policy objective (SNP and the GNP resulting from money stork control is the error in money stock control. 


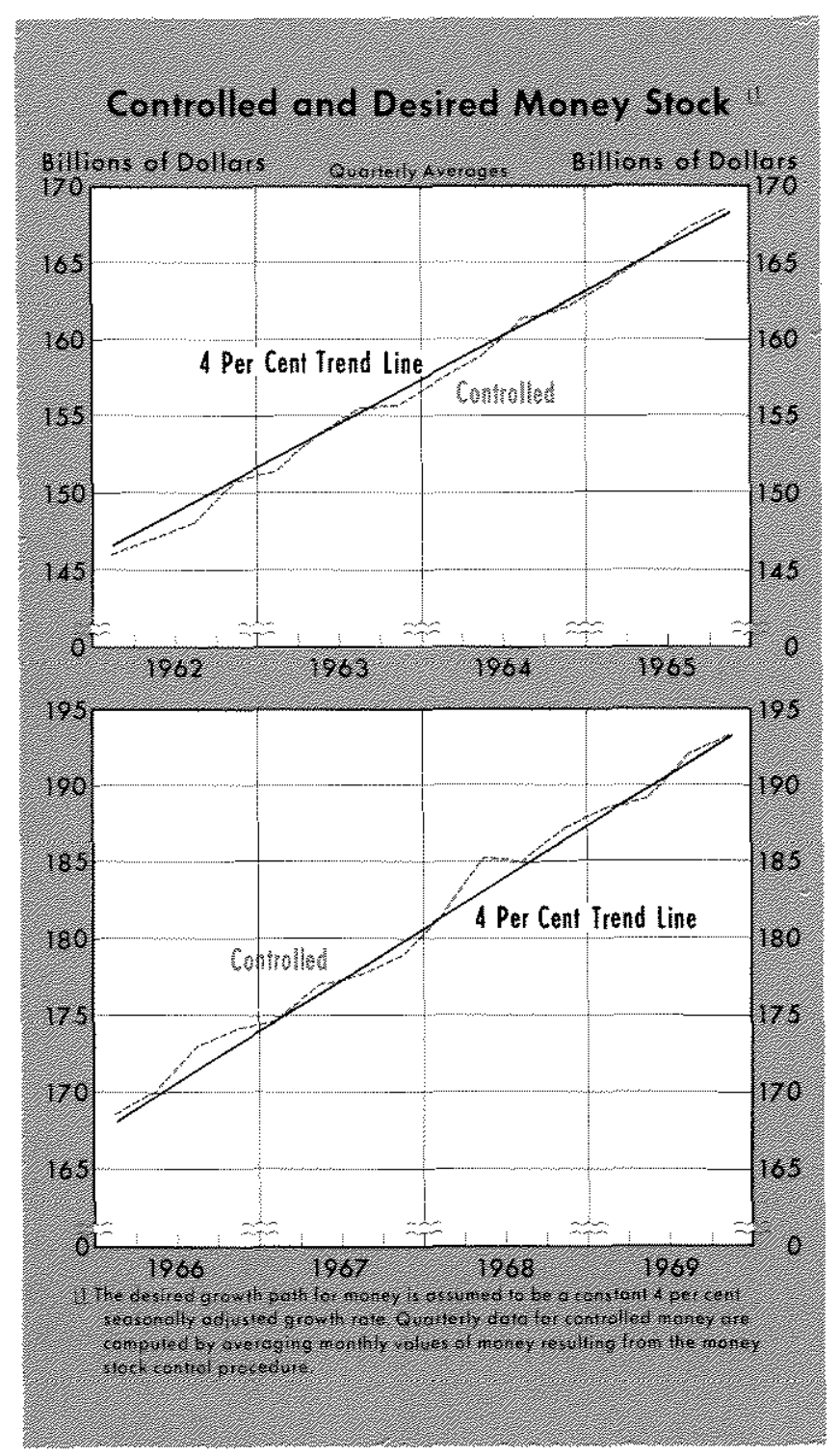

Second, instead of the A-J equation, any other econometric model that relates changes in money to changes in nominal GNP could have been used. Other economists might work out the implications of this and other money control procedures for the ability of policymakers to hit a desired value of GNP, using altemative forecasting and structural models of the econony. Such results would provide valuable supplemental evidence on the adequacy of proposed money stock control procedures.

A third point is that only the infuence of money stock control on nominal GNP was considered. The ultimate objectives of monetary policy are variables such as employment and prices. However, this article is not concemed with the influence of different GNP growth rates on employment and prices. It is assumed that the policymakers pick desired values for employment and prices and then convert these into a desired growth rate of nominal GNP. An analysis of what a given growth of GNP implies for prices and employment could be carried out by using a larger model.

Empirical results - The results of the GNP simulations are presented in Table $I V$ and the following chart. The monetary policynakers are assumed to have chosen objectives for $\mathrm{GNP}$, and then, based on the information they have about the relationship between money and GNP, they have decided that a 4 per cent monetary growth rate will best achieve these GNP objectives. The second column of Table IV contains the growth path of GNP the policymakers desire to achieve (quarterly averages of nominal GNP projected by the A-J equation when a constant 4 per cent growth rate of money is assumed). The first column of this table shows the quarterly averages of nominal GNP projected by the AJ equation when the money stock resulting from our operating procedure for those years is read into the A-J equation.

At an operational level, the Trading Desk is directed to follow an open market policy to achieve the 4 per cent growth rate of money, To carry out its "directive," the Trading Desk forecasts the money multiplier by our procedure, and then supplies the amount of net source base each month that is required to achieve the level of the money stock consistent with the 4 per cent growth of money. Since there are deviations between the quarter-to-quarter growth rate of money achieved by the control procedure and the desired 4 per cent rate, there are deviations of achieved GNP from the policy objective.

Unter the simulation exercise, the success of the policymakers in achieving their desired GNP objectives on average is approximately the same in both sample periods. The largest percentage crror in the levels is seven-tenths of one per cent, and in both periods 10 of the 16 quarterly misses are three-tenths of one per cent or less. The mean fifference between money stock control and policy objective (desired) quarter-to-quarter growth rates of GNP is .01 per cent in the 1962-65 period and .02 per cent in the 1966-69 petiod.

The simulations indicate that the Federal Reserve would have been about equally successful in achieving its GNP objectives in both periods. This result follows from two conditions. First, although there are more frequent large deviations in the achieved money stock in the 1966-69 period, they are not maintained for a long period. On average the degree of control is about the same in both sample periods; deviations 


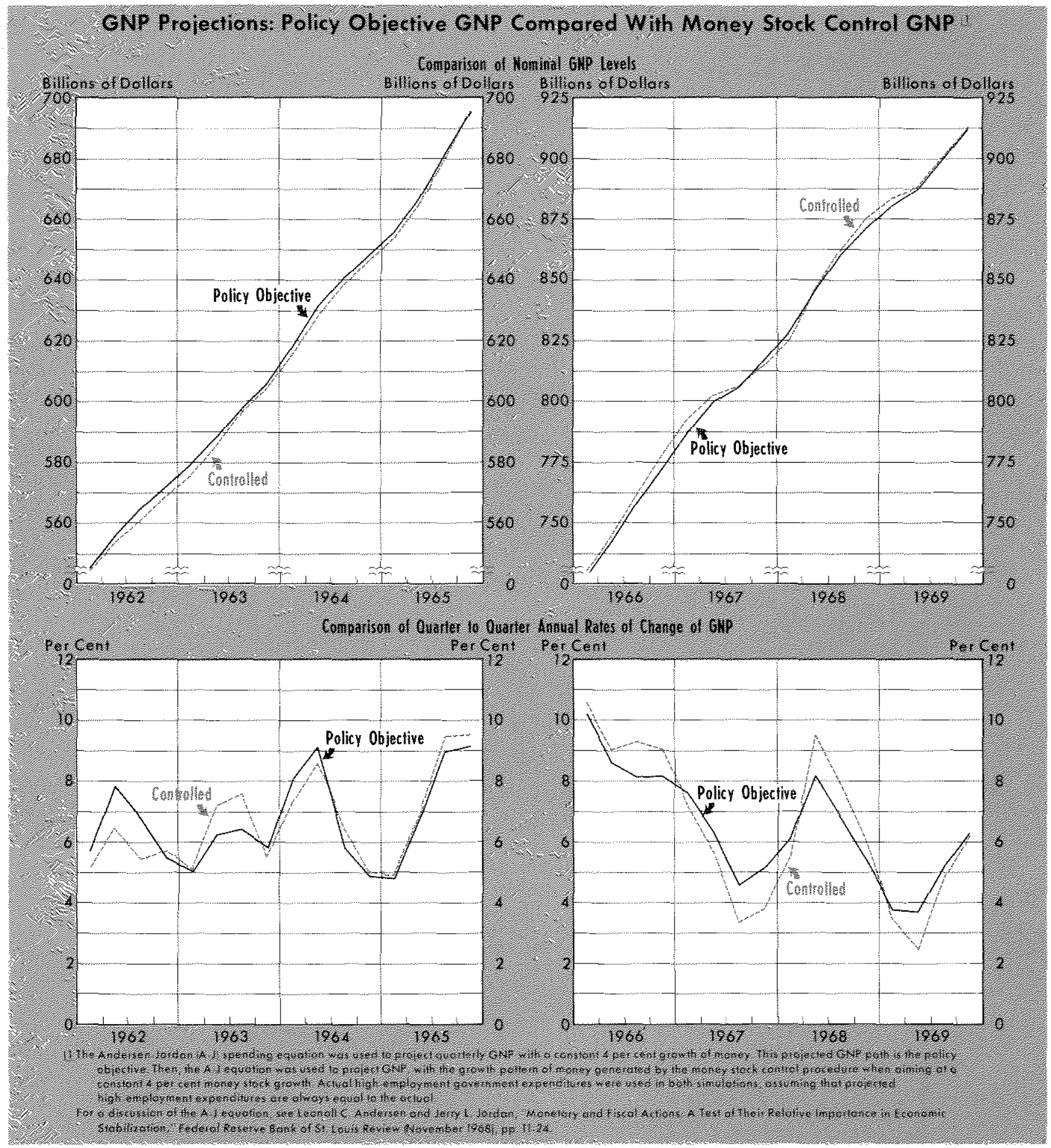

above the desired growth path are followed by deviations below the growth path. Second, in the GNP equation, the infuence of changes in the growth rate of money are distributed over time. The whole impact of a change in money on GNP does not occur in the same quarter. The influence of money on income includes the growth of money over the preceding four quarters.

\section{Assessing the Effect of Money Stock Control on Policy Objectives}

In the previous section, the growth path of GNP profected assuming no errors in money stock control was compared to GNP projected with money stock control using our control procedure. The comparisons were made for two sample periods. However, even 
Table IV

Nominal GNP Levels and Compounded Annual Rates of Change Generated by the Andersen-Jordan Equation

(Billions of Dollars)

1962-1965

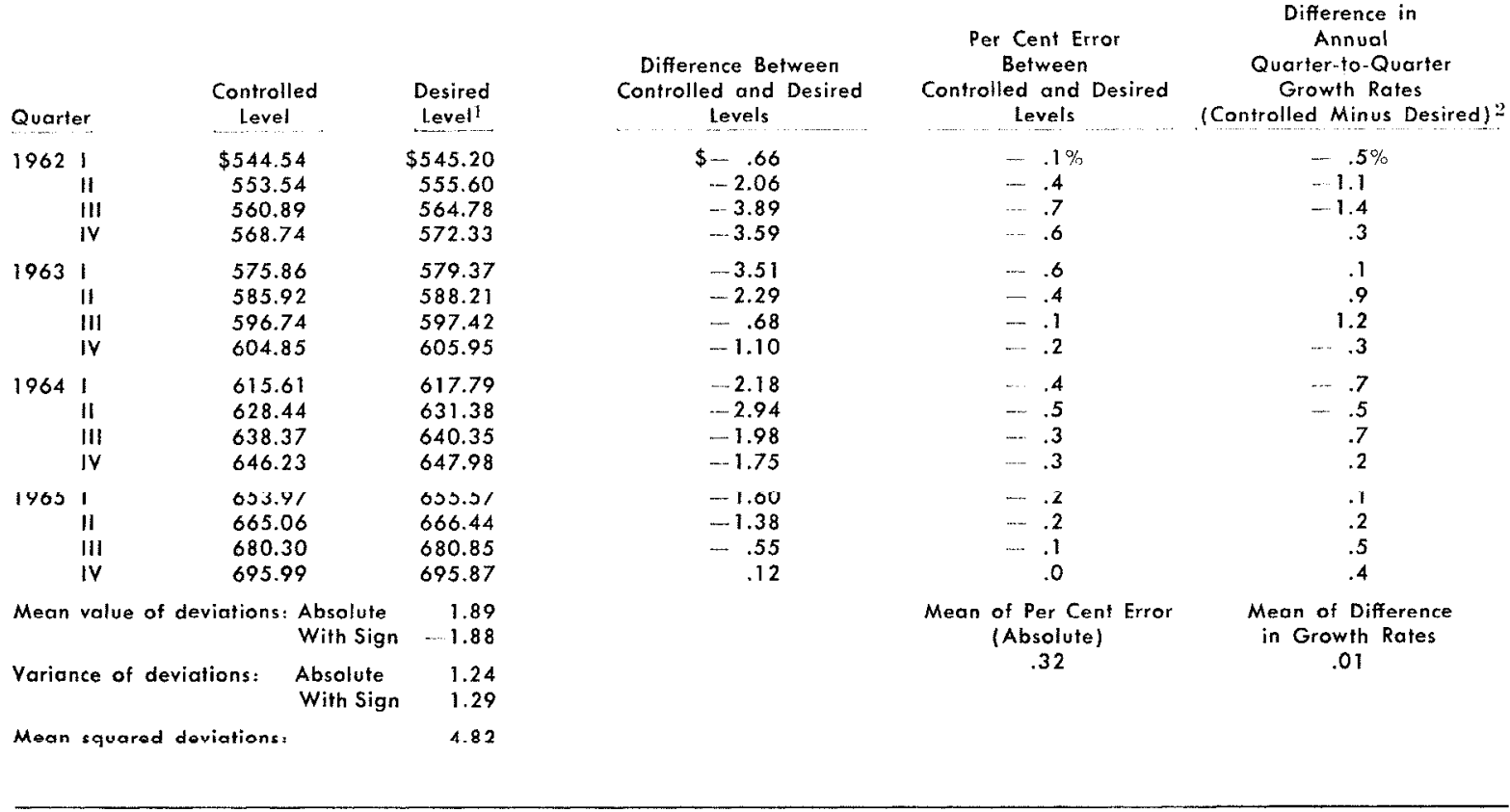

$1966-1969$

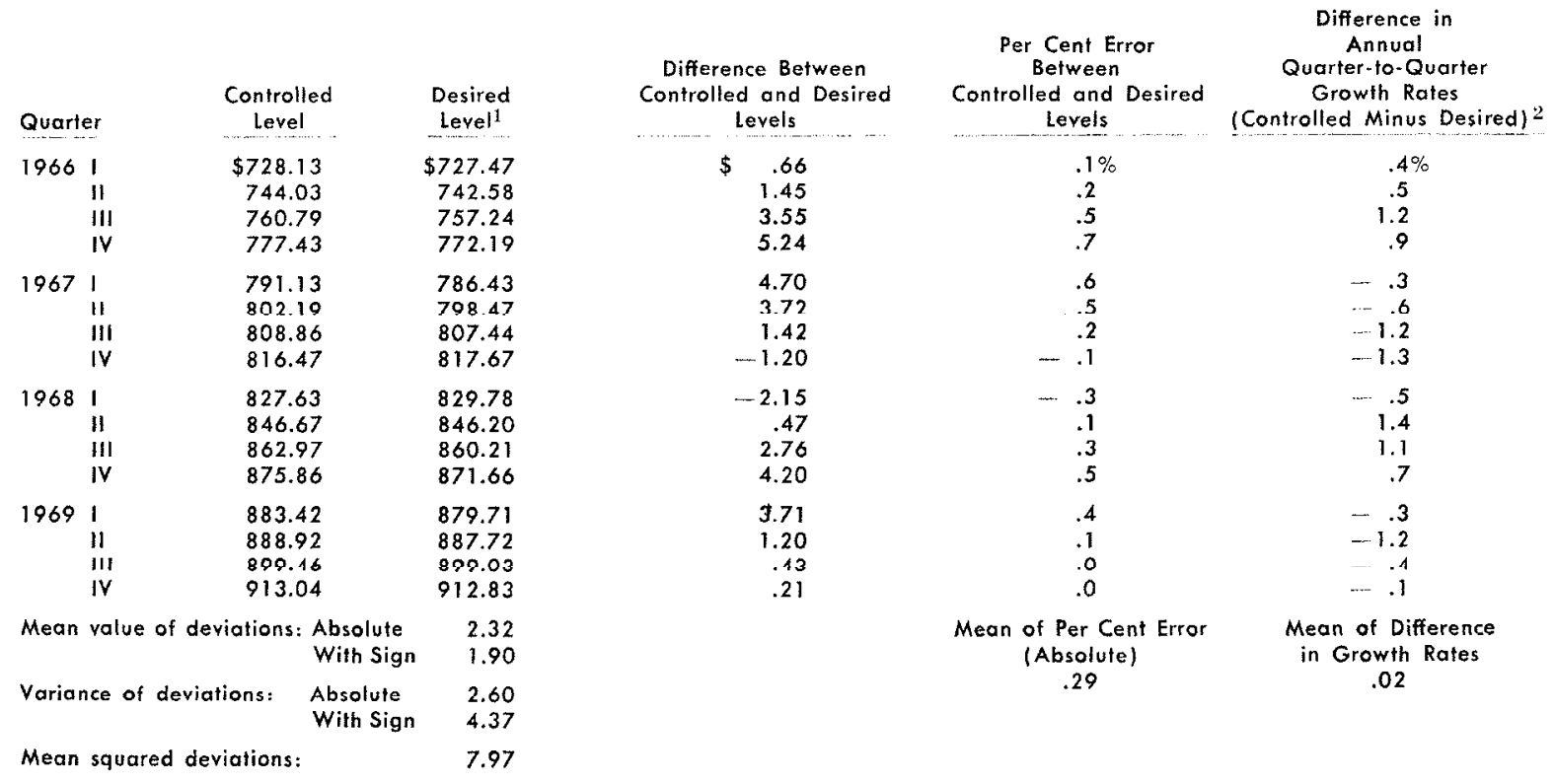

${ }^{1}$ Assuming a simple 4 per cent growth rate for money.

"Compounded annual rates.

Page 16 
though the control procedure worked reasonably well during the sample periods, it will not necessarily do as well in some time interval outside the sample periods."

In an actual policy application, the procedure would be used outside the sample period. Therefore, policymakers mast have some means of assessing what a suggested control procedure implies for their ability to achieve policy objectives in a forecasting situation. This criterion can be a comparison of the ability to attain policy objectives when there are no errors in the control procedure, with the case where there are errors in the control procedure. In this arbicle GNP was chosen as the policy objective, and policy was implemented using a money stock control procedure. Thenefore, the basis for judging the control procedure is the amount by which the errors in money stock control add to errors in forecasting the GNP that would result from a desined growth rate of money.

In this section, representative GNP prediction confidence intervals are presented. In arriving at these confidence intervals, allowance is made for the reliability of the sample estimates of the model's parameters and the multiplier forecasts. A modified standard error of forecast statistic is used to specify confidence intervals for GNP projections when money is controlled. These confidence intervals are then compared with confidence intervals for GNP projections when there are no errors in money stock control...

Table $V$ presents 95 per cent confidence intervals for GNP projections, assuming no errors in money stock control for the four quarters of 1970 . The fmal column in Table $V$ presents the probability of the actual value of GNP falling within these same confidence intervals, given that our control procedure is used to control money. For example, there would have been a 95 per cent probability of actual GNP being within $+\$ 8.64$ billion of the projected level in II/1970, assuming there was no possibility of errors in money stock control. If money had been controlled by our procedure, there would have been a 93.94 per cent probability of actual

\footnotetext{
20 This result can occur because the point estimates of the parameters of the nodel differ from their unobservable population values.

21The deviation of the SEF statistic and the technical aspects of specifying these confidence intervals are discussed in the Appendix at the end of this article, and in the technical appendices available in Work ing Paper No. 14.
}

GNP being within $\$ 8.64$ billion of the projected level. On average, over the four quarters in 1970 , money stock control would have reduced the probability of the actual value of GNP falling within the given confidence interval from 95 per cent to 93.3 per cent. These results indicate that, for 95 per cent confidence intervals, the errors in money stock control implied by our control procedure would have had only a very small effect on the policymaker's ability to forecast GNP.

\section{Conclusions}

The implementation procedure for monetary policy developed th this article provides the basis for a welldefined operational procedure for controlling money. The money stock control procedure does not require the use of any information which the Federal Reserve does not already have available. In fact, it greatly simplifies the operating instructions which would be issued to the Trading Desk. The FOMC would issue a directive to the Trading Desk stated in terms of a growth rate for money. The Desk would convert this growth rate of money into a monthy daily-average net source base figure by using the procedure developed in this article to forecast the monthly money multiplier. During each month, the Desk would use open market operations to set the net source base at the level consistent with the growth rate of money stated in the directive. The Desk would not have to interpret the "consensus of the members of the FOMC." Each month the Desk would have a precise monthly daily-average net source base figure to attain.

Using a simulation technique, this article presented evidence on the effect this money stock control pro-

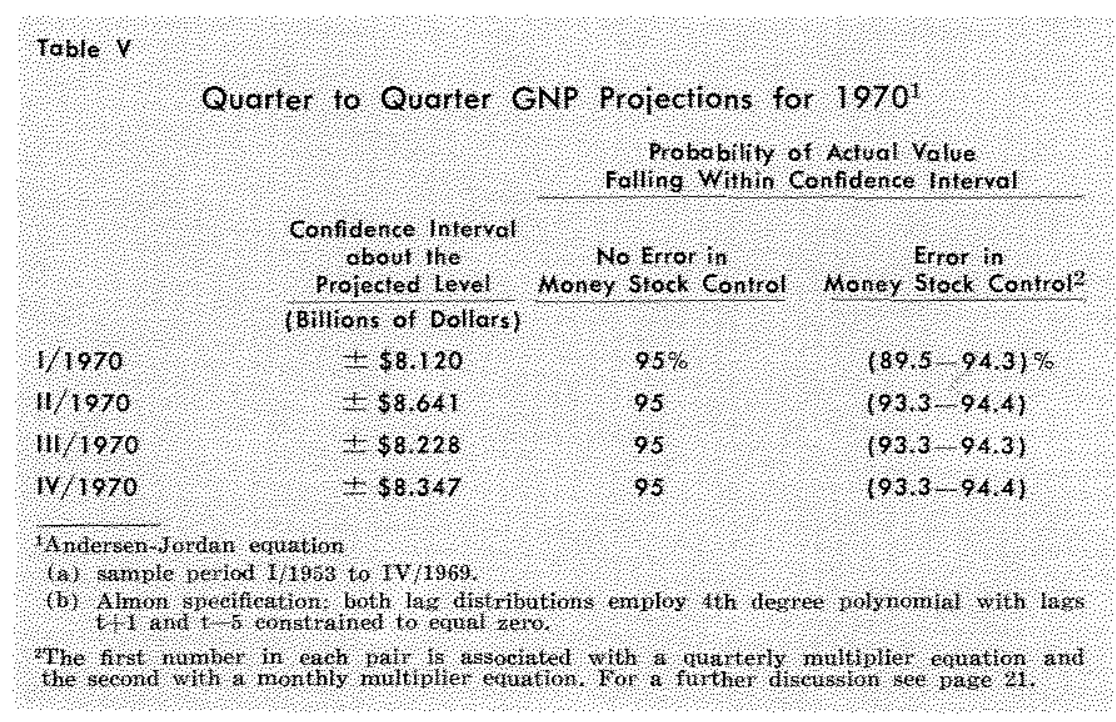


cedure would have had on the ability of policymakers to achieve GNP objectives. In both of the four-year sample periods the largest percentige error in GNP levels was less than one per cent, and in each period 10 of the 16 quarterly GNP errors were three-tenths of one per cent or less. To assess the effect of money stock control, moving outside the sample periods, the standard error of forecast statistic was developed to permit the construction of appropriate confidence intervals for GNP projections. For the fotr quarters of 1970 , the money stock control procedure only reduced the probability associated with the 95 per cent confidence interval to 93.3 per cent.

The final judgement on any monetary policy procedure ultimately rests with the members of the Federal Open Market Committee. As an ideal situation the FOMC would want no errors in achieving their policy objectives. However, this ideal cannot be realized. Therefore, the policymakers must have some means of comparing the effects of different control procedures on their ability to achieve their policy objectives. This article presented some information on these matters for a money stock control procedure.

The Federal Reserve in operating such a money stock control procedure would have additional information that could be used to more closely monitor its control process. The multiplier-base framework used in this article is taken from a fully developed specification of the money supply process, within which the influence of changing economic conditions on the money supply process may be analyzed. Also, a percentage change in the money stock may be decomposed into the percentage changes due to the net source base and the multiplier. The percentage change in the multiplier may then be broken down into the percentage change due to each of its components. For example, at times when large inflows and outllows of time deposits are induced by changes in market rates relative to Regulation $Q$ ceilings, this factor may exert an important influence on the money multiplier. Using this additional information, the Federal Reserve should be able to improve its control of the money stock. ${ }^{22}$

When a money stock control procedure is suggested, a question that is frequently raised is "What does such

\footnotetext{
${ }^{2}$ Also, this procedure does not imply that the value of the multiplier forecast for the coming month at the end of this month shoul be the ote used throughout the month. Each week of the month, as new data on the money stock in the preceding period becomes avalable, a new forecast of the monthy multiplier could be prepared. Based on this additional information, the net source base target for the month might be altered.
}

a procedure imply for the stability of the money market?" The Federal funds rate is commonly used as a summary measure of short-run (daily or weekly) conditions in the money market. If, as implied in our simulations, the Desk had exactly achieved its targeted net source base level each month, would there have been significantly greater fluctuations in the Federal funds rate? The answer to this question required the use of a tested, very short-tem, money market moclel that relates daily or weekly fluctuations in the Federal funds rate to changes in the net source base. Unfortunately, such a model is not available. Using quarterly models, some evidence can be gained on the quarterly average results of money stock control on interest rates. However, these results are not satisfactory to individuals interested in daily or weekly fluetuations.

The money stock control procedure in this article does not necessarily require that the Desk hit the targeted level for the net source base each day or week of the month. The Desk is to attain a dailyaverage monthly net source base target. Therefore, as a practical operating strategy, the Desk would have some latitude to offset short-term shocks to the money market within each month. However, the Desk would have to give primary consideration to achieving the net source base target. The Desk would have to guard against allowing one short-term special situation to be followed by another, resulting in a deviation of the target base level from the one necessary to achieve the desired monetary growth path.

One tentative piece of evidence related to the problem of aggregate control versus money market stability has been presented by Richard Davis. ${ }^{23}$ Davis analyzed the effect that control of nonborrowed reserves would have had on short-term money market rates for a sample period in 1967. He concluded that

Having said that certain features of the experiment tend to overstate the degree of potential money mar. ket instability, however, the writer is inclined to the view that the degree of instability indicated is nevertheless rather surprisingly mild. The computed average absolute weekly change in the Federal funds rate tends to be only around 50 basis points, certanly substantialy larger than the average changes

23Davis method consisted of computing the weekly levels of free reserves that would have resulted during an historical time period if the System had provided a constant weekby-week growth in nonborrowed reserves during that period, given the historical pattern of actual changes in required reserves. An equation relating the Federal funds rate to tree reserves and the discount rate is then used to estimate what the funds rate would have been had the System followed the quantity target. The computed funds rate was then compared to the actual rate for the period. 
that actually occured (around 17 basis points), but not more than the market would seem able to handle without undze stress. $2 *+$

It is important to the well-being of the whole econony that monetary policy be implemented using the procedure that offers the highest probability of policymakers achieving their policy objectives. Other economists have proposed altemative strategies for implementing policy. However, a useful comparison of our procedure with these alternative procedures 24Davis, p. 61 . can only take place when these altematives are explicitly formulated and the effects on GNP of using these procedures is illustrated. Criticism of this money stock control procedure is welcomed. Proponents of other policy procedures are challenged to explicitly formulate their proposals so the effects of these procedtres on attaining policy objectives can be analyzed. In this manmer monetary policy can be implemented and improved on the basis of enpinical evidence, rather than implemented on the basis of conjecture, personal belief, and tradition.

\section{APPENDIX}

In this appendix the technical aspects of the forecasting equation for the money multiplier, the error response mechanism, and the development of the standarf error of forecast statistic are presented.

\section{Forecasting Equation for the Money Multiplier}

Each month's multiplier is forecast using the following equation: ${ }^{5}$

$$
\hat{m}_{t}=b_{0}+b_{1} x_{1 t}+b_{2} X_{2 t}+\sum_{i=1}^{11} b_{1}+q_{2} d_{i}+\rho \mu_{t}+\cdots-1
$$

where: (1) $\mathrm{X}_{1}$ =three month moving average of past value of the multiplier,

$\mathrm{X}_{\mathrm{i}}$ - reserve adjastment magnitude in the forecast month, $\mathrm{d}_{\mathrm{i}}=\underset{\text { dummy variables to account for seasonal }}{\text { factors, }}$

$\rho \quad-\quad$ the correlation coefficient for consecutive error terms in the equation during the sample period,

$\mu_{t-1}=$ lagged value of the error in the estimate of the money multiplier.

(2) The oofficients $b$, are estinated by least squares using the previous 36 months observations. Each month the coefficients are reestimated by adding the most recent month and dropping the first month of the previous 36 observations. $b_{i}$ is an intencept term which also acts

25parameter estimates of the nonthy forecasting equations are included in the technical appendices in Working Paper No. 14.

26Similar results were obtained by omiting the seasonal dummy variables and instead adjusting not seasonally adjusted money by the seasonal factors used by the Federal Reserve. as a seasonal dummy variable. The influence of the $d_{i}$ is to shift the intercept from period to period.

(3) The reserve adjustment magnitude is introdnced to capture the effects of reserve requirement changes. Reserve adjustments are expressed in dollar amomts which are positive when average reserve requirements fall and are negative when reserve recuirements rise. 2

(4) The regression equation's Durbin-Watson (D-W) statistic indicates the existence of significant autoconrelation in the equation's errors. With this condition it is possible to get improved estimates of the money multi. plier over time by including an additional variable in the prediction equation. This variable which "allows" for the alutocorrelation is the lagged value of the error (fu, - 1) in the estimate of the money moltiplier times the correlation coefficient Rho ( $\rho$ ) for consecutive-error terms in the equation during the sample period. ${ }^{2}$

One means of judging the forecasting ability of the multiplier equation is to compare the root mean square

${ }^{27}$ Shifts of deposits between banks with different legal re serve requirements and betweer different deposit categories (demand to time) also exert a slight influence on the month-to-month changes in the reserve magnitude. The variance of the monthly first differences of the reserve adjustment magnitalde diring 1963-69 was six times greater when all rmonths were included, than when months in which reserve requirement changes took place (and adjacent months) were excluded. For the $1962-69$ period, except for months where reserve requirements were changed, the Federal Reserve could have assumed the forecast month's reserve adjustment magnitude would be the sanae as the current month's value withont an appreciable error over the period.

For an explanation of the method by which the reserve adjustment magnitude is computed, see Leonall $C$. Andersen and Jerry L. Jordan "The Monetary Base - Explanation and Analytical Use," this Revieto, August 1968, p. 8 .

28This technique assumed first order autocorrelation. Rho is estimated as

$$
1-\frac{\mathrm{DW}}{2}
$$


error (RMSE) of the forecasting procedure with the RMSE of a no change extrapolation. The RMSE of monthly predictions of the money multiplier in the 1962 65 period was 0151 , which was 53 per cent as large as the RMSE for a no change extrapolation. In the 1966-69 period the RMSE was .0200 , which was 64 per cent as large as the RMSE for a no change extrapolation.

\section{Error-Response Mechanism}

Once there is a possibility of error in money stock control, specification of an optimal operating strategy for changing the net source base requires that the money managers' loss function be specified. There are many possible loss functions, each one representing somewhat different preferences by the policymakers. In our pro cedure a quadratic loss function of the following form is specified:

$$
\begin{aligned}
& \mathrm{L} .=\left(\mathrm{M}-\mathrm{M}^{d}\right)^{2} \quad \begin{array}{c}
\text { money manager's } \\
\text { loss function }
\end{array} \\
& \mathrm{M}=\mathrm{m}_{\mathrm{B}} \mathrm{B} \text {, actual money } \\
& \text { where: } \mathrm{m}_{\mathrm{i}}=\text { money multiplier in period } \mathrm{t} \\
& \mathrm{B}=\text { net source base } \\
& \mathrm{M}^{\mathrm{d}}=- \text { desired money stock in period } \mathrm{t} .
\end{aligned}
$$

In the above expression the product of the money multiplier ( $m$ ) and the net sounce base (B) gives the level of money achieved in period $t$ by our operating procedure. $\mathrm{M}^{\mathrm{d}}$ is the level of money consistent with a given desired growth rate of money. This type of loss function assigns proportionally more weight to large deviations of controlled money from desired than to smaller deviations.

Once the money manager's loss function has been specified, the optimal strategy with respect to the net source base is the one that minimizes the expected value of the loss function. The expected value (where $E$ is used to denote an expected value) for this loss function may be writter:

$$
E(L)=B^{2} \operatorname{var}\left(m_{t}\right)+\left[M^{d}-B E\left(m_{t}\right)\right]^{2}
$$

Minimizing with respect to $B$, gives the following expression for the optimal net sounce base $\left(B^{*}\right)$ :

$$
\left.\mathrm{B}^{*}=\frac{\mathrm{M}^{\mathrm{E}}\left(\mathrm{m}_{\mathrm{t}}\right)}{1+\frac{\mathrm{var}\left(\mathrm{m}_{\mathrm{t}}\right)}{\left[\mathrm{E}\left(\mathrm{m}_{\mathrm{t}}\right)\right]^{2}}}\right]
$$

To calculate the value for $B^{*}$ in any period $t$, (1) we tused $M^{0}$ in period $t$, which is detemined by the desired growth rate; (2) we used $\mathrm{E}\left(\mathrm{m}_{\mathrm{t}}\right)=$ predicted multiplier in period $t$; and $(3)$ var $\left(m_{1}\right)$ was approximated by taking the sum of squared residuals for the multiplier equation and dividing by $36-\mathrm{K}-1$, where $\mathrm{K}$ equals 14 , the number of independent variables in the forecasting equation for the multiplier.

\section{Confidence Intervals for GNP Projections with Money Stock Control}

If a forecasting equation is used in which the money stock is assumed to be controlled by some procedure, then it is necessary to modily the standard error of fore cast statistic associated with the forecasting equation. The importance of errors in money stock control an then be assessed by comparing the SEF of the GNP foreasting equation when there are no errors in money stock control with the standard error of forecast statistic $\left(\mathrm{SEF}{ }^{\circ}\right)$ of GNP estimates when there are errors in money stock control.

One statistic frequently used by economists to assess the forecasting ability of an economic model is the standard error of estimate (SEE). However, a more appropriate measure of the forecasting ability of a model is the correctly specified standard error of forecast (SEF) statistic." The value of the SEF statistic depends upon the values assumed by the independent variables during the forecast period, and upon the variances and covariances of the parameters of the forecasting equation, as well as upon the SEE statistic.

In this section, the SEF statistic which is appropriate for our policy procedure is presented and a comparison of it with the SEF which is associated with the A-I equation when money is assumed to be perfectly controlled is presented.

The equation used in this article to project GNP specifies the quarterly change in GNP as dependent upon current and lagged values of changes in money and government expenditures. To simplify the exposition, and to focls on the effect of errors in money stock control, the change in govenment expenditures is assumed to be predicted without error. Therefore, errors are postulated to exist only in the GNP forecasting equation and in the control of money. The predicted change in money $\left(\Delta \mathrm{M}_{\mathrm{H}}^{\mathrm{T}} \mathrm{n}\right.$ ) in the forecast period and the actual charige in money $\left(\Delta \mathrm{M}_{\mathrm{t}-\mathrm{n}}\right.$ ) are related in the following manner:

where $\theta_{t \rightarrow n}$ is an error term.

$$
\Delta \mathrm{M}_{\mathrm{t}+\mathrm{n}}=\Delta \mathrm{M}_{\mathrm{t}+\mathrm{n}}^{\mathrm{T}}+\theta_{\mathrm{i}+\mathrm{n}}
$$

With errors in the money stock control procedure, an SEF which assumes perfect money stock control is no longer appropriate. This SEF statistic could be too large or too small. "it In other words, policymakers should not use this statistic to construct the conficlence interval for their GNP forecasts. The probability of over-or underestimating GNP could be greater or smaller than that indicated by this SEF statistic.

${ }^{29}$ For a discussion of this subject, see Carl Christ, Econometric Methods and Models, John Wiley Co., 1968, pp. 549-564.

30The derivation of the $S E F$ statistic is presented in the technical appendices available as Working Paper No. 14.

3 For example, if the forecasting equation for the money multiplier results in an overestimate of the money multiplier (which results in the actual money stock being less than the desired), and if, in addition, the A-J equation overestimates the effect of a change in the money stock on GNP, then the influences of the two errors (negative correlation) tend to offset one another. However, when the errors in predicting the money stock and forecasting GNP are in the same direction (positive correlation), then the errors reinforce one another, and the error in GNP forecasts is increased. 
The standard error of forecast statistic $\left(\mathrm{SEF}^{*}\right.$ ) for the A-J equation, assuming errors in money stock control, is given by:

$$
\begin{array}{r}
\mathrm{SEF}^{*}=(\operatorname{SEF})^{2}+\beta_{1}^{2} \operatorname{var}\left(\theta_{\mathrm{t}+\mathrm{n}}\right)+ \\
\left.2 \beta_{1} \operatorname{cov}\left(\theta_{\mathrm{t}+\mathrm{n}}, \varepsilon_{\mathrm{t}+\mathrm{n}}\right)\right]^{1 / 2}
\end{array}
$$

where: SEF denotes the standard error of forecast statistic when there are no errors in money stock control, and $\beta_{1}$ is the coefficient for contemporaneous changes in the money stock in the GNP equation.

Examining the expression for $\mathrm{SEF}^{*}$, it can be seen that the existence of errors in money stock control introduces two extra terms in the standard error of forecast statistic, involving the error in the money stock control procedure $\left(\theta_{t}+\mathrm{n}\right)$ and the error in the GNP equation $\left(\varepsilon_{t, n}\right)$. Terms with the variance $\left(\theta_{t+n}\right)$ and the covariance $\left(\theta_{t}+n, \varepsilon_{t}+n\right)$ are introduced. Since in general these terms are not equal to zero, SEF is mequal to SEF. As remarked earlier, the $\operatorname{cov}\left(\theta_{t+n}, \varepsilon_{t+n}\right)$ may be either positive or negative. If it is positive, then this factor would increase the $\mathrm{SEF} \mathrm{F}^{*}$; if negative, it might be large enough to make $\mathrm{SEF}$. less than $\mathrm{SEF}$. 32

Standard error of forecast statistics are dependent upon the particular values of the independent variables which apply to the prediction period. In particular, an SEF statistic assumes its absolute minimum value when the respective independent variables which enter into it take on values that equal their sample means. All other sets of values of the independent variables will generate larger values of the $\mathrm{SEF}$ statistic. The reason for this result resides in the statistical uncertainty surrounding the regression estimates of the coefficients in the forecasting equation.

For the period $1 / 1953-11 / 1969$, the minimum SEF of the GNP equation is $\$ 3.87$ billion. As an illustration of how the SEF statistic actually differs in practice from its minimum value, let us consider the hypothetical problem of predicting GNP for each of the four quarters of 1970 . Under conditions of perfect money stock control, the $\mathrm{SEF}$ statistic would assume the values given in row $A$ of Table VI which are from approximately 7 to 1 's per cent larger (row B) than the minimum value of the SEF statistic.

For the money stock control procedure, the $\mathrm{SEF}^{*}$ statistics are given in rows $C$ and $F$ of Table $V$. The SEF statistics in row $\mathrm{C}$ correspond to the quarterly average performance of the monthly money stock control proce dure in the simulations with the GNP equation. The $S F^{*}$ statistics in row $F$ correspond to a quarterly money stock control procedure, and are rigorous "outer bounds" to the $S E F^{*}$ statistics given in row $C .3$

32 For any given quarter, it is possible for the $\mathrm{SEF}^{*}$ statistic to be smaller than the traditional SEF statistic if certain conditions are met. Let $\rho$ be the correlation between the error in money stock control $\left(\theta_{t}\right)$ and the error in preficting GNP $\left(\varepsilon_{t}\right)$. The following can be shown to hold.

$$
\text { If } \quad p \leq-1 / 2 \beta_{1}\left[\frac{\operatorname{var} \theta_{t}}{\operatorname{var} \varepsilon_{t}}\right] 1 / 2 \text { holds, }
$$

then $\mathrm{SEF}^{*} \leq \mathrm{SEF}$.

33 The simulation value of $\operatorname{var}\left(\theta_{t}\right)$, or simulation $\operatorname{var}\left(\theta_{t}\right)$, is

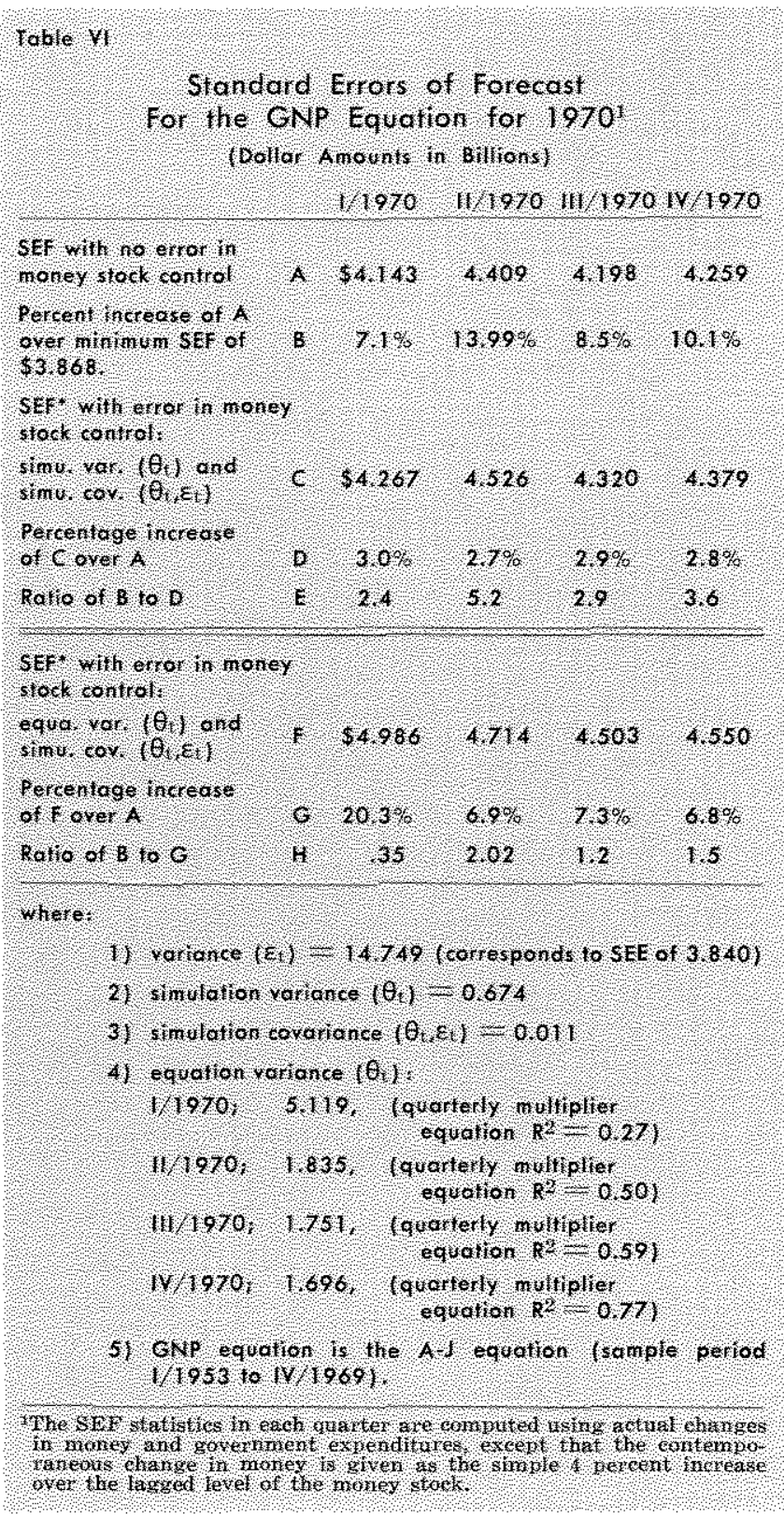

The $\mathrm{SEF}^{*}$ statisties associated with our monthy money stock control procedure are only 3 per cent larger than the SEF statistics assuming no errors in money stock control (see row D). To further understand the implica-

probably the most reasonable estimate for the variance in money stock control, given that a monthly money stock control model is used in coniunction with a cuarterly forecasting model of GNP. Unfortunately, the statistic simula tion $\operatorname{var}\left(\theta_{t}\right)$ makes no allowance for the imprecision in the coefficients of the multiplier forecasting equation. However, as is shown in the technical appendices, this shortcoming can be overcome if the quarterly money stock control procedure is used. In that case, the equation var $\left(\theta_{\mathrm{f}}\right)$ equals $\mathrm{B}_{\mathrm{t}-1}^{2} \times(\mathrm{SEF})^{2}$ (quarterly multiplier equation) which is the most appropriate estimate of var $\left(\theta_{t}\right)$. This variance is just the square of the lagged level of the base times the squared standard error of forecast of the multiplier forecasting equation. 
tions of the standard errors of forecast in $T a b l e ~ V k$, it is helpful to refer back to Table $V$ on page 17 . The data in Table $\mathrm{V}$ show that the errors in money stock control have a negligible effect on the policymaker's ability to forecast GNP, if 95 per cent confidence intervals are used as standards of comparisom. ${ }^{4}$

34 An illustration of how the confidence intervals in Table $Y$ were computed is given below. Consider the perfect money stock control case giver in the first quarter of 1970 entry in row $A$ of Table VI, SEF $\$ 4,143$ billion. Because the errors in predicting changes in GNP can be shown to be normally distributed for large samples (see the technical appendices in Working Paper No. 14), it is appropriate to set up confidence intervals, wsing a table of the standard normal distribution. A range of \pm 1.96 standard deviations gives a 95 per cent confidence interval for the standard nomal distribution, whose standard deviation is unity by defintion.

Consequently, the distribntion of nomally distributed errors with an SEF value of $\$ 4.143$ has a proportionately larger 95 per cent confidenee interval of \pm (1.96) $\times$ (4.143) equals $\pm \$ 8.120$. When errors in money stock control raise the value of the SEF statistic to 84.267 (row C) the vrobability of achieving the same confidence interval of $\pm \$ 8.120$ billion is reduced to 94.26 per cent, since now only \pm 1.90 standard deviations of the standard normal distribution will give that same confidence interval, [i.e., $\pm(1.90) \times(4.26 i)$ equals \pm 8.120 ]

For a comparison of 90 and 80 per cent confidence intervals see the technical appendices available in Working Paper No. 14 .

This article is available as Reprint No. 72.

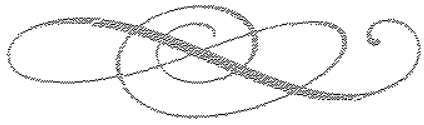

